that once again the new building occupied by the Institute in 1928 was paid for by citizens of Bergen. Besides being professor of oceanography, HellandHansen, until he resigned his professorship in 1946, was head of the Institute, which houses also Departments of Meteorology and of Cosmic Physics and Terrestrial Magnetism.

The scope and range of Helland-Hansen's enterprise and achievement embraced yet another project. In 1925 he was one of three trustees nominated by the testator to administer the residual estate of more than five million krøner of the late Christian Michelsen, a former Prime Minister of Norway and millionaire shipowner. As the Chr. Michelsen Fund, the estate endowed the establishment in 1930, and the maintenance, of a Chr. Michelsen Institute of Science and Intellectual Freedom. Besides compiling the statutes for its administration, Helland-Hansen, as chairman of the Board of Administrators, was for twenty-five years the presiding genius in its conduct.

He was the recipient of many honours, among which may specifically be cited the honorary rank of a Commander, with Star, of the Order of St. Olav, and the Portuguese Order of the Great Cross of St. Jago. $\mathrm{He}$ was doctor honoris causa of several universities and a fellow of numerous scientific and learned societies in Europe and America. Medals, in commemoration mostly of oceanographical research expeditions or investigators, were awarded him on many occasions. He was elected president of the International Association of Physical Ocoanography in 1936 and president of the International Union of Geodesy and Geophysics in 1945.

Helland-Hansen died in Bergen on September 7, 1957, and the sympathy of countless colleagues, friends, and admirers the world over is offered to his widow, Anna Marie Krag, of Copenhagen, whom he married in 1902, and their family of one daughter and five sons.

J. B. TAIT

\section{Prof. M. Damodaran}

Prof. Manayath Damodaran, who died after a prolonged illness last December, was a graduate of the University of Madras, and after some preliminary training in research at the Indian Institute of Science, Bangalore, he was awarded a Government of Madras Research Studentship. He spent his first year in Germany with Abderhalden at Halle a.S., where he worked on the preparation and enzymic digestion of myristic acid peptides, and his last two years with me at the Imperial College of Science and Technology, London. He was then, as he always remained, a quiet unassuming scholar, and he already possessed the connoisseur's appreciation of research, a quality that his friends slways found so attractive, and which inspired his own students later in Madras and Poona. Until recent years his main interest was in protein chemistry and metabolism, a field in which he was a pioneer in India and by far its best exponent. At heart he was an analyst and never happier than when applying his great experimental skill to problems concerned with amino-acid analysis of proteins.

At the Imperial College he was responsible, during 1929-32, for the isolation of asparagine and glutamine from enzymic digests of edestin and gliadin respectively, an achievement which provided the first direct proof of the 'amide hypothesis' in proteins and gained him the degree of D.Sc. (London). On his return to India at the end of 1932 he was made first reader and then professor in his old University at Madras, a post he held for sixteon years. There, in spite of very limited laboratory equipment, he embarked on a series of researches which soon made him one of the foremost biochemists in India. One may mention his work on phosphopeptone from casein, the isolation of canavanine from many seeds, new sources of urease, and the proteins of local foodstuffs. He also demonstrated for the first time the presence of glutamic dehydrogenase in plants, which he found in germinating seedlings. The results of all these valuable researches were accepted for publication in the Biochemical Journal.

In 1948 came the call to the new National Chemical Laboratory in Poona, where he was invited to assume directorship of the Biochemical Department and later the deputy-directorship of the Laboratory. At first the task was rather an uphill one, as accom. modation was limited and equipment scarce. But in the early 1950's, with the new building in operation, conditions improved, and during his last five years or so Damodaran had at his disposal a laboratory as well equipped as any in Europe or America. The National Chemical Laboratory had been created to fulfil a national need, and Damodaran never lost sight of this aspect of his job. In the early stages of its development, proteins had to be relegated to the background and prominence given to problems that might have economic or medical application. For example, he bred a remarkably active and reliable strain of Aspergillus niger for the production of citric acid from sugar, and his process based on it is now in commercial operation. The synthesis of ascorbic acid from sorbitol, with a 99 per cent inter. mediary yield of sorbose, has also passed the pilot stage. Another important line he introduced was a gelatin plasma substitute preparation, based on a tryptic digestion, which has already been tested clinically with excellent results. Damodaran entered whole-heartedly into the work of the National Chemical Laboratory, and his retirement through ill-health in the summer of 1956 was deeply regretted by the Director and all his staff. All who knew him in Britain and India will mourn the passing of a very lovable colleague.

A. C. Chibnall

\section{Prof. Claude Fromageot}

Cradde Fromageot, director of the Laboratory of Biological Chemistry at the Faculté des Sciences, Paris, since 1946 and professor of biochemistry at the Sorbonne since 1954, died on January 10, at the age of fifty-eight. The unexpected loss of this distinguished scholar comes as a great shock to his many friends all over the world.

Fromageot received his early scientific education at the Institut National Agronomique. After a year at the Collège de France, he spent a further year as assistant to Victor Henri at Zurich. In 1928 he went as a Rockefeller Fellow to Berlin-Dahlem, where he worked in the laboratory of Carl Neuberg. In 1929 he became director of the Biochemical Laboratory at the Faculté des Sciences at Lyons, and there he remained (with an interruption of ten months in 1933 spent at the University of Wisconsin, in Madison) until he went to Paris in 1946.

His early work was devoted mainly to the study of bacterial fermentations, particularly to the relation between fermentation and respiration in Propione. bacterium pentosaceum. In later years he became 
interested in the study of the chemical composition of proteins endowed with biological activity; for example, of lysozyme and of the pituitary hormones. Some of his more recent results in this field were presented at Bristol in April 1956, when he took part in the Colston Research Society Symposium on the neurohypophysis.

Fromageot's name is most intimately connected with our present knowledge of the metabolism of sulphur, both in micro-organisms and in higher animals. Much of this work was reviewed in his Harvey Lecture, given in New York in 1953. One of the main advances that we owe to him and his colleagues is the recognition of the central position held by cysteinesulphinic acid in the degradation of cysteine. They discovered and investigated a number of enzymic reactions in which this important intermediate metabolite takes part. The role of vitamin $B_{6}$ in these reactions and the action of hormones on the enzymes involved have been studied in his laboratory. Many of these results are embodied in the "Colloque sur la Biochimie du Soufre", the outcome of a gathering held in May 1956 at the Station Maritime, Roscoff, under the auspices of the Centre National de la Recherche Scientifique, where Fromageot and his colleagues discussed outstanding problems with other workers in this field. Here his unique mastery of the subject was evident, and this volume will now serve to remind us of some of his more recent achievements and of his aims. At the time of his death, Fromageot was busy planning another session on sulphur metabolism for the Fourth International Congress of Biochemistry, to be held at Vienna this year.

Fromageot did much to strengthen international co-operation in research. He travelled widely and lectured in many countries, helped by his great linguistic abilities. Biochemists everywhere owe him a debt, as one of the founders of Biochimica et Biophysica Acta, and as the president of the Organizing Committee of the Second International Congress of Biochemistry, held at Paris in 1952.

In the remarkable development of French biochemistry in the post-war years, Fromageot played his full part. Some of his earlier colleagues followed him from Lyons to Paris; later his name attracted an ever-increasing number of workers from France as well as from many other countries. He was able in recent years greatly to develop his laboratory from its modest beginnings and to provide it with modern equipment. It is sad to think that his untimely death did not allow him to direct for a longer period what had grown into one of the world's leading centres of biochemical research. H. BLAschko

\section{NEWS and VIEWS}

Entomology at McGill :

Prof. E. M. DuPorte

Prof. E. M. DuPorte, who is retiring from the chair of entomology at MaeDonald College, McGill, was born on the island of Nevis in the British West Indies and received his first college education at Basseterre on St. Kitts. He went to Canada in 1910 as a student at Macdonald College and has been attroched to that institution either as a student or as a member of the staff throughout his academic life. He took his Master's degree in 1914 and his Ph.D. in 1921. Morphology became his prineipal interest, and his world-wide reputation was earned in this field. Prof. DuPorte has played an important part in establishing and maintaining the reputation of Macdonald College as a graduate school. He taught a remarkably wide range of subjects : ecology, protozoology, histology, parasitology, insect taxonomy, morphology, physiology, comparative vertebrate anatomy and embryology, and was one of the two members of the committee responsible for the establishment of the present Institute of Parasitology at Macdonald College. In spite of his wide range of interests in his own subjects, he has still found time for other activities, and is a keen golfer as well as a puppet player who builds and handles his own puppets. His friends and students thoroughout Canada will wish him a happy and enjoyable retirement.

Dr. D. K. McE. Kevan

THE appointment of Dr. D. K. McE. Kevan to succeed Prof. DuPorte at Macdonald College, McGill, will be welcomed by his many friends in Britain and Europe. Dr. Kevan graduated from the University of Edinburgh with first-class honours in zoology in 1941, and proceeded to the Imperial College of Tropical Agriculture, Trinidad, where he obtained his associateship in 1943. He was then appointed to the Colonial Service, and stationed in Kenya, where he became interested in the problems of the taxonomy of locusts and other bush hoppers. These have remeined his abiding interest, and in a series of able papers he has undertaken considerable revision of the classification of certain Orthoptera, especially Chrotogonus, and has brought some degree of order to what had been a. confused and tangled field.

$\mathrm{He}$ returned to England in 1948 as the senior member of the agricultural zoology section of the youngest Faculty of Agriculture in Britain, at the newly established University of Nottingham. In this, his first teaching post, he quickly established a reputation as an able teacher, and he played an active part in developing the curriculum for the new structure of the degree. He has been active both in the prosecution and in the encouragement of research, and a remarkable stream of papers has flowed from his department. His work in taxonomy has been assisted by a wide knowledge of foreign languages which is becoming unusual in a scientist, and papers in both German and French testify to his fluency. More recently he has become interested in soil zoology and has developed an effective undergraduate course in this field, while his own key for the identifica. tion of soil-inhabiting fauna, published with the Proceedings of the Second Nottingham Easter School in Agricultural Science, constitutes something of a classic. A critical and independent mind, he has been an admirable tutor, whose succinct reports on the vagaries as well as the virtues of both male and female students will be sadly missed by his colleagues at Sutton Bonington.

\section{Civil Engineering at Nottingham:}

$$
\text { Dr. R. C. Coates }
$$

DR. R. C. CoATES, who was appointed to the newly established chair of civil engineering in the University of Nottingham on January 1, began his education at 